\title{
Deradikalisasi Agama Melalui Kegiatan Keagamaan di Masjid Kampus Ulul Azmi Unair Surabaya
}

\author{
Muhammad Syarif Hidayatulloh, Fitri Nurhidayati \\ Unversitas Maarif Hasyim Latif, Sidoarjo, Indonesia \\ Syarif_hidayatulloh@dosen.umaha.ac.id Fitri_Nurhidayati@dosen.umaha.ac.id
}

\begin{abstract}
Various studies on radicalism in Non-Religion Higher Education show that the institutions are not sterile from this movement. If it is left, in the next few years, it will cause disintegration of the nation. Besides for worship, the campus mosque is the most effective means of spreading radicalism through structured studies among students. This study examines the efforts of the Ulul 'Azmi campus mosque of C Airlangga University in Surabaya to counteract radicalism among students. This study is a qualitative research with the descriptive analysis. The results of this study indicate that the efforts for the caretaker of the Ulul 'Azmi mosque Airlangga University are by strengthening moderate Islamic ideology and nationalist insights and imposing strict permits on study groups conducted by external organizations. The study material is also determined by the mosque management with moderate and tolerant principles. This study is expected to be able to provide solutions for the development of understanding of religious radicalism in universities through campus mosques
\end{abstract}

Keywords: Campus Mosque, Religious Deradicalization, Religious Activity

\begin{abstract}
Abstrak
Berbagai kajian tentang adanya radikalisme di Perguruan Tinggi Umum menunjukkan babwa intitusi pendidikan pun tidak steril dari gerakan ini. Hal ini jika dibiarkan beberapa tabun kedepan dikhawatirkan akan menimbulkan disintregasi bangsa. Masjid kampus yang merupakan tempat ibadah juga sebagai sarana paling efektif untuk menyebarkan pabam radikalisme melalui kajian-kajian yang terstuktur dikalangan mabasiswa. Penelitian ini mengkaji bagaimana upaya masjid kampus Ulul 'Azmi kampus C Universitas Airlangga (Unair) Surabaya dalam menangkal paham radikalisme dikalangan mahasiswa. Penelitian ini merupakan penelitian kualitatif dengan menggunakan analisis deskriptif. Hasil dari penelitian ini menunjukkan babwa upaya yang dilakukan oleb pengurus masjid Ulul 'Azmi Unair yakni dengan cara penguatan ideologi Islam moderat dan wawasan kebangsaan serta memberlakukan izin yang ketat terhadap kelompok kajian yang dilakukan oleb organisasi eksternal. Materi kajian juga ditentukan oleb pengurus masjid dengan prinsip moderat dan toleran. Artikel ini dibarapkan mampu memberi solusi atas berkembangnya paham radikalisme agama di perguruan tinggi melalui masjid kampus.
\end{abstract}

Kata kunci: Masjid Kampus, Deradikalisasi Agama, Kegiatan Keagamaan

Permalink/DOI: https://doi.org/10.18326/infsl3.v13i2.305-328 


\section{Latar Belakang}

Salah satu fungsi masjid kampus yang dianggap strategis sebagaimana pada umumnya masjid yang dibangun masyarakat adalah sebagai tempat menumbuhkan suasana religius di perguruan tinggi. Setidaknya, mampu mewadahi civitas akademika yang memilki hasrat yang kuat untuk memperdalam ilmu agama sekaligus mensyi'arkan ajaran agama Islam.

Pada periode awal, masjid tidak semata sebagai sarana ibadah atau tempat sujud an sich. Bahkan Nabi Muhammad menggunakan fasilitas masjid sebagai pusat kegiatan pengkaderan, pendidikan, sosial budaya, ekonomi dan politik bagi umat Islam. Dengan masjid sebagai sentra kegiatan ini memudahkan Nabi Muhammad dalam membetuk karakter umat Islam karena para sahabat setiap hari bertemu mendapat pendidikan dan arahan atas kegiatan tersebut dari Nabi Muhammad (Kurniawan, 2014, p. 169).

Dewasa ini banyak masjid yang telah didirikan oleh masyarakat muslim Indonesia baik yang dibangun dari swadaya masyarakat yang keberadaanya di tengah perkampungan atau yang didirikan oleh lembaga atau instansi tertentu yang sangat mudah dijumpai sebagaimana masjid yang berada dilingkungan kampus. Di beberapa perguruan tinggi, masjid terlihat sebagai tempat alternatif bagi mahasiswa untuk mengisi kegiatan diluar jam perkuliahan. Kenyataan ini terus berkembang sehingga masjid kampus bukan hanya berfungsi sebagai tempat ibadah tapi juga sebagai tempat diskusi kelompok, pengembanagan seni budaya, kegiatan ekstra kurikuler, latihan kemimpinan dan lain sebagainya (Djunaidi, Irfan, \& Safitri, 2016)

Akan tetapi, akhir-akhir ini peran masjid dihadapkan pada tantangan yang sangat besar dan komplek, ini disebabkan derasnya arus informasi dan IPTEK yang membawa dampak negatif bagi masyarakat Indonesia khusunya kalangan muda. Selain itu, tantangan yang harus disikapi dengan serius oleh masjid adalah adanya ideologi radikal yang mulai merembet ke masjid-masjid terutama masjid kampus yang merupakan sarana paling strategis bagi penyebar ideologi radikal untuk melakukan doktrinisasi terhadap kalangan mahasiswa. 
Hasil penelitian Setara Institut mengungkap fakta menarik terkait adanya sepuluh kampus yang terpapar radikalisme yaitu Universitas Indonesia (UI), Intitut Teknologi Bandung (ITB), Universitas Gajah Mada (UGM), UNY, UIN Jakarta dan Bandung, IPB, Universitas Brawijaya (UNBRAW), UNIRAM, dan Universitas Airlangga (UNAIR) (Abdi, 2019). Hal ini mengindikasikan bahwa radikalisme sudah merangsek kedalam kampus yang merupakan masyarakat akademisi. Golongan ini akan semakin tumbuh subur apabila dibiarkan tanpa adanya perlawanan dari berbagai pihak termasuk kalangan kampus. Upaya-upaya harus terus dilakukan untuk mencegah menjalarnya arus radikalisme dikalangan mahasiswa terutama mereka yang ada di kampus sekuler seperti diatas. Meski kurikulum di perguruan tinggi umum seperti diatas sudah terdapat mata kuliah agama (Pendidikan Agama Islam), namun porsi yang diberikan tidak sesuai dengan kebutuhan mahasiswa. Akibatnya, tidak sedikit mahasiswa yang haus terhadap ilmu agama mencari pengalaman diluar jam perkuliahan dengan mengikuti kegiatan keagamaan yang biasanya berpusat di masjid kampus.

Menurut Chairul ada dua faktor yang mempengaruhi seseorang dapat bersikap radikal. Pertama, adanya faktor eksternal, yaitu adanya informasi yang 'salah' yang diperoleh dari orang lain sehingga mampu mendorong dirinya terjerumus dalam radikalisme. Faktor eksternal ini bisa dari guru maupun informasi media eletronik maupun media sosial yang saat ini merambah di dunia remaja. Kedua, faktor internal yaitu, dorongan kuat dari dirinya sendiri untuk berbuat radikal dan ekstrim (Mahfud, Prasetyawati, Wahyuddin, Agustin, \& Sukmawati, 2018).

Tidak sedikit masjid kampus yang membuat kegiatan keagamaan untuk memperdalam wawasan keagamaan bagi mahasiswa, bahkan ada sebagian kampus yang mewajibkan mahasiswa barunya untuk mengikuti kegiatan mentoring agama. Seringkali kelompok radikalisme menjadikan mentoring ini sebagai pintu masuk untuk menyebarkan ideologinya dikalangan mahasiswa.

Oleh sebab itu, keberadaan masjid kampus sangat vital baik dalam rangka penyebaran ideologi islam radikal sekaligus sebagai sarana untuk mencegahnya. Atas dasar inilah penulis tertarik untuk 
meneliti peran masjid kampus dalam upaya menangkal paham radikalisme agama di lingkungan mahasiswa di Surabaya. Tujuan dari penelitian ini adalah untuk mengetahui kegiatan yang dilakukan oleh pengelola masjid dalam upaya menangkal paham radikalisme agama dikalangan mahasiswa.

\section{Metodologi Penelitian}

Metode yang dipakai dalam penelitian ini menggunakan metode kualitatif deskriptif yang ditujukan untuk menggambarkan fenomena-fenomena yang ada, yang berlangsung saat ini atau pada saat yang lampau (Syaodih Sukmadinata, 2009). Objek utama penelitian ini adalah aktivitas keagamaan masjid Ulul 'Azmi yang berada di kampus C Universitas Airlangga Surabaya dalam upaya menangkal paham radikalisme agama dikalangan mahasiswa. Pengumpulan datanya melalui wawancara, observasi dan dokumentasi. Data dikumpulkan dari informasi dan sumber-sumber di lapangan. Data yang dikumpulkan kemudian dikategorikan, diklasifikasikan, dikurangi, dianalisis, dan kemudian ditafsirkan dalam konteks masalah penelitian untuk mendapatkan kesimpulan. Prosedur yang dilakukan dalam penelitian ini merupakan penelitian yang memfokuskan pada pemecahan masalah dengan cara mendeskripsikan dan menggambarkan kondisi obyek dan subyek penelitian. Baik yang berupa institusi, individu (seseorang), maupun masyarakat berasaskan fakta dan keadaan yang apa adanya.

\section{Kerangka Teori}

Masjid Kampus

Kehadiran masjid kampus dapat menjadi angin segar bagi pengembangan dakwah untuk menciptakan mahasiswa yang berilmu, bertaqwa, beramal dan berkarakter Islami. Masjid kampus memiliki peran penting dalam pengembangan keilmuan keislaman semenjak berdirinya Lembaga Dakwah Kampus (LDK) di masing-masing kampus. Untuk mewadahi aktivis dakwah kampus seluruh Indonesia dan semakin semaraknya kegiatan keagamaan oleh LDK, secara resmi pada tahun 2004 dibentuk Asosiasi Masjid Kampus Indonesia (AMKI).

Masjid Kampus selama ini berperan sebagai media komunikasi 
dalam rangka menjalankan agenda kegiatan dan pengkaderan mahasiswa Islam (Tahir et al., 2014, p. 187). Selain itu, masjid juga digunakan sebagai sarana mengembangkan potensi dan bakat mahasiswa yang berkaitan dengan kegiatan keagamaan seperti pelatihan khitobah, seni baca Al-qur'an, seni sholawat dan lain sebagainya. Hal ini dilakukan dengan tujuan agar masjid kampus mampu memberikan sumbangsih dalam pembentukan karakter sekaligus penanaman ideologi terhadap mahasiswa khusunya dibidang agama.

Setiap hari, bahkan hari-hari libur masjid kampus masih terlihat ramai dengan berbagai aktifitas yang dilakukan oleh civitas akademika. Mereka menggunakan masjid kampus untuk pembinaan ketaqwaan dan keimanan serta pengkaderan. Diantaranya adalah adanya kajian-kajian secara berkelompok yang dilaksanakan oleh mahasiswa yang menambah suasana tampak hidup di lingkungan masjid kampus.

Jika dilihat dari sifatnya, secara umum masjid kampus memilki dua bentuk kegiatan. Pertama, kegiatan rutin. Kegiatan ini biasanya dilaksanakan satu minggu sekali atau satu bulan sekali yang dikoordinasikan oleh pengurus masjid. Pengurus masjid menentukan narasumber sekaligus kitab yang dijadikan pegangan sebagai referensi dalam kegiatan rutin. Kedua, kegiatan insidental atau situasional. Seperti halnya kegiatan rutin, kegiatan insidental juga dikoordinir dan dijadwal oleh pengurus masjid kampus seperti PHBI (Peringatan Hari Besar Islam).

Baik kegiatan rutin maupun insidental keduanya melibatkan mahasiswa sebagai bagian dari kepengurusan masjid yang diseleksi terlebih dahulu dan disahkan oleh rektorat. Kegiatan-kegiatan yang dilaksanakan di masjid kampus bukan hanya program pengurus masjid kampus, tetapi terkadang juga kegiatan-kegiatan yang bersifat alamiah muncul dari keinginan dan usulan dari jamaah sendiri.

Selain itu, program tutorial atau mentoring keagamaan tampaknya merupakan ciri khas aktivitas masjid kampus. Bagi beberapa kampus program ini merupakan kegiatan kokurikuler dari mata kuliah Pendidikan Agama Islam (PAI) yang masuk dalam bobot penilaian mata kuliah PAI, dan adapula hanya sebagai kegiatan kurikuler murni. Dari segi kepengurusan, masjid kampus sebagaima- 
na lazimnya masjid juga terdapat struktur organisasi kepengurusan masjid kampus yang ditunjuk langsung oleh rektor dan disahkan melalui Surat Keputusan (SK).

\section{Radikalisme Agama}

Kamus Besar Bahasa Indonesia (KBBI) mengartikan kata radikal "secara mendasar, maju dalam berpikir atau bertindak" (Depdikbud, 1995, p. 808). Sementara itu Encarta Dictionaries yang dikutip oleh syarif mengartikan kata radikal sebagai "Favoring major changes: favoring or making economic, political or social changes of sweeping or extreme nature". (membantu terjadinya perubahan-perubahan besar, terutama membantu terjadinya atau membuat perubahan ekonomis, politis, atau perubahan social secara luas dan ekstrim) (Hidayatulloh, 2015, p. 11).

Sementara Nur Syam mengemukakan definisi radikalisme dengan paham yang melekat pada satu kelompok tertentu yang memiliki keyakinan bahwa ajaran agama yang dianggap bertentangan dengan apa yang mereka pahami harus diganti dan menuntut perubahan terhadapnya. Meski harus dilakukan dengan cara merobohkan sistem yang sudah berjalan dengan cepat hingga ke akar-akar nya atas dasar subyektifitas pemahaman keagamaan kelompok tertentu (Nur Syam, n.d., p. 242).

Jika ditelisik dalam perspektif sejarah, gerakan radikalisme agama yang muncul di Indonesia memiliki tautan yang erat dengan tumbuh kembangnya aliran salafi di Timur Tengah yang terjadi pada abad 12 Hijriah. Kelahiran salafisme atau paham salafi yang menginginkan pemurnian ajaran agama Islam dan yang selalu mengajak kembali kepada al-Qur'an dan Hadist Nabi ini dipolopori oleh gerakan wahabi yang didirikan oleh Muhammad ibn 'Abd al-Wahhab (1703-1787) dari Nejd. Pemurnian agama yang dimaksudkan kelompok wahabi merujuk pada pengamalan ajaran agama sebagaimana yang dipraktekkan oleh umat Islam generasi pertama.

Kelompok radikalisme agama yang ada saat ini memiliki ciri takfir (mudah mengkafirkan), tabdi' (mudah membid'ahkan) dan tasyrik (mudah mensyirik kan). Mereka hanya meyakini kebenaran tunggal dan tidak mau kompromi dengan pendapat yang berseberangan dengan mereka. Apapun yang bertentangan dengan pa- 
ham mereka dianggap salah dan sesat. Sikap seperti inilah yang pada akhirnya memunculkan watak intoleransi, kaku dan fanatik berlebihan. Adapun beberapa faktor penyebab terjadinya gerakan Islam radikal diantaranya adalah: faktor agama, faktor sosial-politik, faktor pendidikan, faktor cultural, faktor ideologis anti westernisasi (Laisa, 2014: 6).

Marx Juergensmeyer sebagaimana yang dikutp Syarif berpendapat bahwa radikalisme adalah bentuk sikap yang mengharap perubahan terhadap status quo dengan cara penghancuran secara menyeluruh dan menggantinya dengan sesuatu yang berbeda dan bentuk yang baru (Hidayatulloh, 2015, p. 34). Secara sederhana radikalisme dapat diartikan dengan berlebihan dalam menjalankan ajaran agama.

\section{Mahasiswa}

Dalam kamus besar bahasa Indonesia mahasiswa diartikan sebagai orang yang sedang belajar di salah satu perguruan tinggi, dan dalam struktur pendidikan yang ada di Indonesia ini mahasiswa memegang status pendidikan yang paling tinggi diantara lainya (Depdikbud, 1995). Sementara mahasiswa memilki peran yang sangat penting, menurut siallagan ada tiga peran dasar mahasiswa : (1) peran intelektual. Ia mampu menjalani hidupnya secara proposional baik sebagai mahasiswa, anak maupun harapan masyarakat. (2) peran moral. Sebagai warga kampus yang dikenal dengan bebas ber ekspresi, beraksi, berdiskusi, berspekulasi, dan berorasi memiliki tanggung jawab moral tanpa terkontaminasi oleh lingkungan. (3) peran sosial. Mahasiswa yang dikenal sebagai agen of change mampu berfikir kritis, bersinergi dan bertindak konkrit yang terbingkai dalam keikhlasan menjadi pelopor dan pengabdi masyarakat (Saputra, 2015, p. 12).

Azumardi Azra sebagaimana yang dikutip oleh Djunaidi membagi corak berpikir keagamaan mahasiswa ke dalam tiga kelompok: Pertama, kelompok "common" Muslim yang merupakan kelompok mayoritas, mereka adalah para mahasiswa Muslim yang mengamalkan ajaran Islam secara tradisional dan konvensional serta seadanya. Kedua, kelompok yang memiliki latar belakang keagamaan yang kuat serta memilki keinginan yang menggebu untuk mengembang- 
kan potensi dirinya. Mereka punya keinginan untuk menambah dan memperdalam wawasan tentang Islam sekaligus berorganisasi sebagai wadah aktualisasi diri dan keterampilan ilmiah. Dalam mewujudkan aktualisasi dirinya mahasiswa tipe ini memiliki kecenderungan untuk berorganisasi dengan bergabung dengan organisasi yang bergerak dalam bidang keagamaan baik yang internal kampus seperti LDK dan UKKI (Unit Kegiatan Kerohanian Islam) maupun yang eksternal seperti Pergerakan Mahasiswa Islam Indonesia (PMII) dan Himpunan Mahasiswa Islam (HMI).

Ketiga, kelompok mahasiswa yang lebih memilih mengamalkan ajaran Agama dengan cara kaffah atau secara menyeluruh. Terdapat beberapa kemungkinan atas fenomena gaya beragama kelompok ketiga ini dan diantaranya adalah adanya pengaruh organisasi internasional atau paham transnasional seperti Jama'at Islami dari Pakistan, Ikhwanul Muslimin dari Mesir serta beberapa kelompok lain yang mulai menyebarkan ideologinya dan mengembangkan pahamnya di Indonesia. Bisa pula atas kretivitas mahasiswa Indonesia yang mengadakan kajian-kajian keislaman secara intensif dalam bentuk halaqah maupun usrah.

Kegiatan mentoring agama atau tutorial keagamaan yang sering dijumpai di masjid kampus merupakan hasil kreasi kelompok ini termasuk juga kegiatan pesantren kilat bagi pelajar seingkat SD hingga SMA (Djunaidi et al., 2016, p. 286). Steffen Hertog dan Diego Gambetta pernah melakukan kajian terkait keterlibatan mahasiswa dalam gerakan radikalisme. Hasil dari kajian tersebut mengemukakan bahwa latar belakang disiplin keilmuan mahasiswa memiliki pengaruh terhadap penerimaan radikalisme. Mahasiswa yang terdapat dalam keilmuan eksakta memiliki kerentanan terhadap radikalisme (Laksana, 2017).

Data diperoleh dari ratusan aktivis Islam yang terpapar radikalisme agama yang diambil dari 30 negara yang terdapat di benua Afrika dan Timur Tengah. Mereka mayoritas lahir antara tahun 1950 dan 1970 an. Menariknya, data tersebut juga mengungkap beberapa mahasiswa Indonesia yang terlibat dalam gerakan radikalisme. Diantara hasil penelitian yang diungkap menunjukkan bahwa gerakan radikalisme ini justru memikat hati bagi mereka yang memilki pen- 
didikan tinggi atau orang yang berada. Sementara anak muda yang tingkat ekonominya rendah malah kurang begitu tertarik dengan gerakan ini seperti yang diyakini masyarakat Indonesia.

Lebih jelasnya, secara prosentase, tiga atau bahkan empat kali lebih besar para engineeers atau insinyur memiliki kecenderungan yang kuat untuk menjadi radikal-teroris meskipun juga ditemukan mereka yang menekuni bidang profesi kedokteran, keuangan, maupun ilmu eksakta yang lain (the science). Data lain juga menyebutkan bahwa 60\% sejumlah teroris di barat berasal dari bidang ilmu engineering atau teknik. Selanjutnya, delapan dari 25 teroris yang beraksi saat melakukan serangan 11 Septembeer 2001 berasal dari latar belakang ilmu teknik. Apabila melihat dari hasil penelitian secara keseluruhan maka menunjukkan angka $44,9 \%$ yang terlibat gerakan radikalisme adalah mereka lulusan dari fakultas teknik dan memiliki ijazah teknik (Laksana, 2017, p. 11).

Peneltian yang dilakukan oleh kedua peneliti diatas tampaknya diamini oleh Munawwir Syadzali yang selaku menteri Agama saat itu pernah melontarkan pernyataan kontroversial sebagaimana yang dikutip oleh Nur Syam. Beliau menyatakan bahwa gerakan radikalisme Agama di Indonesia tumbuh dan berkembang pada perguruan tinggi yang terdapat prodi ilmu eksakta termasuk didalamnya fakultas teknik. Meski tidak ada argumentasi atas pernyataan tersebut Nur Syam juga sepakat bahwa fakultas saintek lebih kondusif atas berkembangnya paham radikal.

Senada dengan pernyataan diatas, cendekiawan Muhammadiyah, Zuli Qodir yang pernah melakukan kajian terhadap gerakan radikalisme yang tumbuh di Universitas Gajah Mada (UGM) yogyakarta juga memberikan pernyataan bahwasanya masuknya paham radikalisme justru lebih banyak terdapat pada fakultas Kedokteran, fakltas teknik dan fakultas matematika dan Ilmu Pengetahuan Alam atau MIPA. Lanjut beliau, untuk saat ini paham radikalisme sudah mulai merangsek ke fakultas lain bahkan ke universitas lain seperti Universitas Muhammadiyah Yogyakarta, Universitas Negeri Yogyakarta dan Universitas Islam Indonesia serta perguruan tinggi negeri lain. 


\section{Deradikalisasi Agama Melalui Masjid Kampus}

Faktor ideologi merupakan salah satu penyebab berkembangnya paham radikalisme agama di kalangan mahasiswa. Mahasiswa yang sudah terkena virus radikalisme dan sudah tertanam kuat dalam dirinya tentu sudah melalui berbagai proses panjang. Proses panjang tersebut dilakukan oleh mahasiswa secara intens melalui serangkaian tukar pendapat, perdebatan dan diskusi mendalam hingga pada akhirya doktrin radikalisme mudah diterima oleh mereka (Saifuddin, 2017, p. 8).

Pertemuan ideologi radikalisme agama dengan kalangan mahasiswa tentu bukan sesuatu yang kebetulan dan tiba-tiba muncul ditengah-tengah kampus. Gerakan radikalisme agama dapat muncul di lembaga pendidikan setingkat kampus karena adanya jaringan diluar kampus yang intens melakukan komunikasi dengan yang didalam. Dengan demikian gerakan radikalisme agama membuat metamorfosa dengan merekrut mahasiswa, sebagai kalangan terdidik.

Sebagai upaya menyebarkan paham radikalisme mereka tidak segan untuk 'menyerang' kelompok atau golongan yang berbeda paham dengan mereka. Tuduhan syirik, bid'ah, khurofat dan idiom lainya yang memojokkan seringkali digunakan untuk melemahkan tradisi keagamaan yang sudah mengakar di masyarakat. Dan masjid merupakan sarana paling efektif untuk doktrinasi hal tersebut tidak terkecuali masjid kampus. Usaha yang dilakukan oleh mereka akhir-akhir ini menunjukkan hasil yang cukup signifikan yakni banyak perubahan pada kehidupan beragama masyarakat terutama yang terjadi pada generasi milenial dengan istilah 'hijrah'. (Muhsin, Rochmawati, \& Huda, 2019, p. 45).

Masjid kampus memilki peran strategis dalam menangkal radikalisme agama dikalangan mahasiswa. Selain sebagai tempat ibadah, masjid kampus berfungsi sebagai sarana memperdalam ilmu agama dalam bentuk kajian-kajian keislaman. Kelompok radikalisme agama seringkali menggunakan masjid sebagai sarana doktrinasi ideologi agama terhadap mahasiswa. Hal ini dikuatkan oleh Anas Saidi -peneliti LIPI- yang mengungkap bahwa proses masuknya gerakan radikalisme agama dikampus dilakukan dengan 
cara menguasai masjid kampus. Mereka melakukan doktrinasi agama terhadap mahasiswa dengan pemahaman agama yang sempit, kaku yang berujung pada sikap intoleran (Lestari, 2016).

Selama ini sudah ada ikhtiyar dari berbagai lapisan masyarakat guna mengatasi penyabaran paham radikalisme termasuk upaya yang dilakukan oleh pemerintah melalui densus 88 maupun dengan membentuk Badan Nasional Penanggulangan terorisme. Namun, yang perlu diketahui bahwa ideologi tidak bisa 'dihabisi' begitu saja dengan cara kekerasan, akan tetapi juga dilakukan sebuah upaya 'perlawanan' atas ideologi radikal dengan mengajarkan ideologi moderat dan toleran.

Oleh sebab itu, gerakan deradikalisasi agama perlu terus digalakkan guna mencegah menyebarnya paham radikalisme agama terutama dikalangan mahasiswa. Mahasiswa yang dianggap sebagai anak muda terdidik tidak lepas dari sasaran ideologi radikalisme agama. Sementara masjid kampus adalah sarana paling efektif untuk melakukan kontrol terhadap kegiatan keagamaan baik yang diadakan oleh pihak kampus maupun organisasi eksternal.

Deradikalisasi dalam pandangan Nasir Abbas sebagaimana dikutip oleh Syarif merupakan upaya sistematis untuk membangun kesadaran pada masyarakat bahwa fanatisme sempit, radikalisme dan fundamentalisme dapat memunculkan gerakan terorisme (Hidayatulloh, 2015). Menyikapi kondisi seperti ini, beberapa kampus negeri melalui pimpinan kampus membuat kebijakan strategis dengan tujuan menekan infiltrasi gerakan radikalisme di kampus. Dan sudah semestinya kebijakan tersebut berkait erat dengan kegiatan keagamaan dilingkungan kampus yang berpusat di masjid kampus sebagaimana hasil penelitian penulis di masjid Ulul 'Azmi kampus C Universitas Airlangga Surabaya.

\section{Penguatan Materi Islam Moderat}

Menurut Direktur Kemahasiswaan Universitas Airlangga Hadi Shubhan bahwa kegiatan yang diselenggarakan oleh Mahasiswa Masjid Ulul Azmi berpijak pada prinsip Tasamub (toleran) dan Tawassuth (moderat). Hal ini dapat dilihat dari bentuk kajian yang telah diadakan oleh pengurus dan mahasiswa masjid Ulul Azmi. Salah satu upaya yang dilakukan oleh pengurus masjid Ulul Azmi 
dalam rangka menangkal paham radikal agama adalah dengan cara memberikan penguatan materi Islam wasathiyyah atau Islam yang moderat melalui materi kajian keagamaan. Wawasan tentang Islam moderat, terbuka dan toleran sangat dibutuhkan mahasiswa sebagai imunitas dari maraknya arus radikalisme agama. Dalam tulisanya, Toto suharto mengemukakan bahwa Islam moderat ialah Islam yang bukan ekstrem atau radikal, yang senantiasa tidak menekankan pada kekerasan atau tidak menempuh garis keras di dalam mengimplementasikan keberislamannya (Toto, 2017). Sementara terminologi moderat merupakan sebuah penegasan bahwa Islam sangat menolak kekerasan atas dalih apapun, karena dalam sejarahnya tindak kekerasan akan memunculkan kekerasan baru dan hal ini tidak sesua dengan prinsip Islam Rabmatan lil 'Alamin (Miftahuddin, n.d., p. 4).

Ada dua bentuk kajian keagamaan yang diadakan di masjid Ulul 'Azmi, yaitu kajian harian dan kajian situasional, dengan jadwal kegiatan seperti tercantum pada tabel 1. Kajian situasional merupakan kajian yang dilaksanakan pada momen tertentu seperti PHBI (Peringatan Hari Besar Islam) dan PHBN (Peringatan Hari Besar Nasional). Kajian harian yang dimaksud disini adalah kajian yang diadakan setiap hari aktif perkuliahan yakni mulai hari senin sampai jumat dengan materi yang berbeda. Jamaah menggunakan Kitab kuning sebagai bahan rujukan dalam kajian harian. Kitab kuning yang dipilih merupakan kitab yang sering dipakai di pesantrenpesantren di Indonesia dan merupakan kitab standar bagi kalangan masyarakat muslim Indonesia.

Dilihat dari kandungan kitab yang dipakai kajian, menurut penulis setidaknya ada tiga jenis kitab, yaitu: pertama, kitab yang muatan isinya berupa pencerahan spritual dan olah jiwa yang lebih menekankan bagaimana cara taqarrub kepada Allah melalui muhasabah nafsi dan mujahadah seperti, kitab al-Hikam karya SyekhIbnu 'Athaillah Al-Iskandary, mursyid besar generasi ketiga dalam Tarekat Syadziliyyah dan kitab Ibya' Ulumiddin karya Abu Hamid Imam AL-Ghazali. Dijelaskan dalam sebuah penelitian, seseorang yang mengkaji secara intens karya Ibn 'Athaillah ini, dapat memiliki kemampuan mengontrol diri dan meningkat rasa optimisme dalam memaknai hidup dengan nilai-nilai Islam (Adityani 
Putri, 2018). Hal ini dikarenakan kandungan kitab al-hikam berisi tentang Tauhid, Akhlaq dan Tasawwuf yang dapat melembutkan hati. Begitupula kandungan dari kitab Ihya' yang menitikberatkan pada pentingnya akhlaq melalui konsep takhalli, tahalli, dan tajalli. Zaky Mubarak, sebagaimana yang telah dikutip oleh khoirun Nisa', pernah mengatakan bahwa kitab Ihya' Ulum al-Din dapat menjadikan 'alim dan berakhlaq bagi pembacanya (Nisa', 2016).

Kedua, kitab Hujjah Amaliah dan Addifa'. Kitab ini menjelaskan dalil-dalil atau argumen tentang tradisi agama masyarakat muslim Indonesia berdasarkan pada teks al-qur'an, Hadist maupun pendapat ulama seperti tradisi dzikir berjamaah setelah sholat, mendoakan orang yang sudah meninggal, perayaan maulid Nabi dan tradisi keagamaan yang lain yang seringkali tradisitradisi ini oleh kelompok radikal dianggap tradisi syirik, bid'ah dan sesat yang pelakunya dianggap 'kafir' dan keluar dari Islam. Sebagaimana yang diutarakan oleh AS Hikam, diantara ciri kelompok radikalisme agama adalah mudah mengkafirkan, membid'ahkan dan menyalahkan tradisi keagamaan yang sudah mengakar pada masyarakat muslim Indonesia yang dimana ajaran semacam ini bersumber dari kelompok Wahabi (A.S. Hikam, 2016). Kelompok ini menolak dan menyesatkan segala hal praktik keagamaan yang dianggap tidak murni dan tidak di sebutkan dalam teks al-Qur'an dan Hadist yang seringkali juga disebut sebagai kelompok Islam puritan (Muhsin \& Gufron, 2018). Tuduhan-tuduhan yang tidak berdasar atas perilaku keagamaan semacam ini sangat mengkhawatirkan terhadap hubungan sosial masyaarakat muslim Indonesia. Hal ini dikarenakan dapat memicu munculnya sentimen kelompok dan agama yang dapat menimbulkan sikap intoleransi. Maka dari itu, perlunya menjawab tuduhan tersebut berdasar argumen naqli ataupun aqli sebagai bentuk upaya pembelaan terhadap tradisi keagamaan masyarakat muslim Indonesia. Dan hal ini telah di upayakan oleh penguruus masjid Ulul Azmi dalam memberikan wawasan keagamaan kepada para jamaahnya.

Ketiga, pendalaman materi keagamaan secara umum, seperti kitab Syarah Hadist Jibril karya Habib Zen Ibn Ibrahim Ibn Smith yang membahas tentang Islam, Iman, dan Ibsan yang masing-masing memunculkan disiplin ilmu yang berbeda. Islam dijabarkan menjadi 
ilmu Fikih, Iman menjadi ilmu tauhid sementara Ihsan memunculkan ilmu Tasawuf. Secara umum, isi kitab tersebut berupa penjelasan dasar dari rukun Islam, rukun Iman dan ihsan. Penjelasnya runtut, tidak bertele-tele, tidak menyentuh pada persoalan khilafiyah dan lebih pada penguatan materi diatas. Jika dilihat dari paham yang dianut oleh penulisnya, kitab ini merupakan kitab pegangan kelompok ablu sunnab wal jamaah yang memiliki watak toleran dan moderat.

Apabila melihat beberapa kitab yang digunakan oleh pengurus masjid Ulul 'Azmi diatas tidak ditemukan adanya ideologi atau ajaran yang mengajarkan kekerasan dan intoleran, akan tetapi bahkan lebih mendidik para pelajar atau mahasiswa untuk bersikap lemah lembut, menonjolkan kasih sayang dan memilki akblaqul karimah. Hal ini menurut penulis merupakan bentuk deradikalisasi agama melalui kegiatan kajian yang mengedepankan toleransi dalam beragama. Ada dua makna toleransi yang diutarakan oleh sebagian pakar. Pertama, bahwa toleransi itu cukup dengan membiarkan dan tidak menyakiti orang atau kelompok lain yang berbeda pendapat. Kedua, selain tidak menyakiti dan membiarkan hak orang lain juga mendukung atas keberadaan orang atau kelompok lain tersebut (Abdullah, 2011, p. 13). Dalam konteks Indonesia, bentuk toleransi yang dilakukan oleh para pendahulu dalam menyebarkan agama Islam dengan cara damai dan menghargai budaya yang telah ada serta tidak memaksa orang lain untuk memeluk Islam.

Tabel 1. Jadwal Kajian Masjid Ulul Azmi Kampus C UNAIR Surabaya

\begin{tabular}{|c|c|c|c|c|c|c|}
\hline \multicolumn{7}{|c|}{ Jadwal Kegiatan Masjid Ulul 'Azmi (Mingguan) } \\
\hline No. & Hari & Kajian & $\begin{array}{l}\text { Nara } \\
\text { Sumber }\end{array}$ & Peserta & Waktu & $\begin{array}{l}\text { Tem } \\
\text { pat }\end{array}$ \\
\hline \multirow[t]{4}{*}{01.} & $\begin{array}{l}\text { Senin } \\
\text { Pertama }\end{array}$ & $\begin{array}{l}\text { Kitab Ihya' } \\
\text { Ulumiddin }\end{array}$ & $\begin{array}{l}\text { Ust. Choi } \\
\text { ruddin }\end{array}$ & $\begin{array}{l}\text { Umum/ } \\
\text { Mahasiswa }\end{array}$ & 16.15 & $\begin{array}{l}\text { Ruang } \\
\text { Utama }\end{array}$ \\
\hline & $\begin{array}{l}\text { Senin } \\
\text { kedua }\end{array}$ & $\begin{array}{l}\text { Hujjah } \\
\text { Amaliah }\end{array}$ & $\begin{array}{l}\text { Ust. Ma'ruf } \\
\text { Khozin }\end{array}$ & $\begin{array}{l}\text { Umum / } \\
\text { Mahasiswa }\end{array}$ & 16.15 & $\begin{array}{l}\text { Ruang } \\
\text { Utama }\end{array}$ \\
\hline & $\begin{array}{l}\text { Senin } \\
\text { ketiga }\end{array}$ & $\begin{array}{l}\text { Tafsir } \\
\text { Tematik }\end{array}$ & $\begin{array}{l}\text { Ust. Junaidi } \\
\text { Sahal }\end{array}$ & $\begin{array}{l}\text { Umum / } \\
\text { Mahasiswa }\end{array}$ & 16.15 & $\begin{array}{l}\text { Ruang } \\
\text { Utama }\end{array}$ \\
\hline & $\begin{array}{l}\text { Senin } \\
\text { ketiga }\end{array}$ & Al-Hikam & $\begin{array}{l}\text { Ust. Abdul } \\
\text { loh Bahreisy }\end{array}$ & $\begin{array}{l}\text { Umum / } \\
\text { Mahasiswa }\end{array}$ & 18.15 & $\begin{array}{l}\text { Ruang } \\
\text { Utama }\end{array}$ \\
\hline
\end{tabular}




\begin{tabular}{|c|c|c|c|c|c|c|}
\hline & $\begin{array}{l}\text { Senin } \\
\text { keempat }\end{array}$ & $\begin{array}{l}\text { Kitab } \\
\text { Addifa' }\end{array}$ & $\begin{array}{l}\text { Habib Mahi } \\
\text { Al-Muhdlor }\end{array}$ & $\begin{array}{l}\text { Umum / } \\
\text { Mahasiswa }\end{array}$ & 16.15 & $\begin{array}{l}\text { Ruang } \\
\text { Utama }\end{array}$ \\
\hline 02. & Selasa & $\begin{array}{l}\text { Fiqih } \\
\text { Pernikahan }\end{array}$ & $\begin{array}{l}\text { Ust. Afri } \\
\text { Andiarto }\end{array}$ & $\begin{array}{l}\text { Umum / } \\
\text { Mahasiswa }\end{array}$ & 16.15 & $\begin{array}{l}\text { Aula } \\
\text { Bawah }\end{array}$ \\
\hline 03. & Rabu & $\begin{array}{l}\text { Arbain } \\
\text { Annawawi }\end{array}$ & $\begin{array}{l}\text { Ust. Afri } \\
\text { Andiarto }\end{array}$ & $\begin{array}{l}\text { Umum / } \\
\text { Mahasiswa }\end{array}$ & 16.15 & $\begin{array}{l}\text { Aula } \\
\text { Bawah }\end{array}$ \\
\hline 04. & Kamis & $\begin{array}{l}\text { Tahsin Al- } \\
\text { Qur'an }\end{array}$ & $\begin{array}{l}\text { Ust. } \\
\text { Nuruddin }\end{array}$ & Mahasiswa & 16.15 & $\begin{array}{l}\text { Aula } \\
\text { Bawah }\end{array}$ \\
\hline 05. & Jumat & $\begin{array}{l}\text { Kajian Kemus } \\
\text { limahan }\end{array}$ & & $\begin{array}{l}\text { Umum / } \\
\text { Mahasiswa }\end{array}$ & 16.15 & $\begin{array}{l}\text { Aula } \\
\text { Bawah }\end{array}$ \\
\hline \multicolumn{7}{|c|}{ Jadwal Kegiatan Masjid Ulul 'Azmi (Situasional) } \\
\hline 01. & PHBI & Kondisional & Kondisional & $\begin{array}{l}\text { Umum / } \\
\text { Mahasiswa }\end{array}$ & $\begin{array}{l}\text { Kondi } \\
\text { sional }\end{array}$ & $\begin{array}{l}\text { Ruang } \\
\text { utama }\end{array}$ \\
\hline 02. & PHBN & Kondisional & Kondisional & $\begin{array}{l}\text { Umum / } \\
\text { Mahasiswa }\end{array}$ & $\begin{array}{l}\text { Kondi } \\
\text { sional }\end{array}$ & $\begin{array}{l}\text { Ruang } \\
\text { Utama }\end{array}$ \\
\hline
\end{tabular}

\section{Penguatan Wawasan Kebangsaan}

Menurut L.B. Moerdani yang dikutip oleh Wahyono S.K. wawasan kebangsaan memiliki tiga hal pokok yang harus di hayati dan di implementasikan secara menyeluruh agar tumbuh kesadaran berbangsa yang kuat. Adapun ketiga wawasan kebangsaan tersebut terdiri dari (1) rasa kebangsaan (2) faham kebangsaan dan (3) semangat kebangsaan (S.K., 2017). Rasa kebangsaan adalah rasa yang tumbuh secara alami dalam diri masyarakat disebabkan adanya kebersamaan sosial yang timbul dari kesamaan tantangan di masa lampau dan kesamaan menghadapi tantangan masa kini. Selain itu, tumbuh kembang rasa kebangsaan juga dilatar belakangi oleh kesamaan budaya, sejarah serta aspirasi perjuangan di masa lalu. Berbagai tantangan masa lalu hingga sekarang yang dihadapi mengalami dinamisasi perubahan dalam menggapai cita-cita bangsa yang kemudian berkembang menjadi wawasan kebangsaan atau faham kebangsaan yang memilki semangat mewujudkan cita-cita kehidupoan dan tujuan yang jelas secara nasional. Atas dasar inilah, kemudian timbul semangat kebangsaan atau patriotisme (Hadi, n.d.)

Gebernur Lemhanas, Muladi mendefinisikan wawasaan kebangsaan adalah cara pandang bangsa Indonesia mengenai diri dan lingkunganya, mengutamakan kesatuan dan persatuan wilayah dalam penyelenggaraan kehidupan bermasyarakat, berbangsa dan 
bernegara (Gumelar, 2018, p. 6). Penguatan wawasan kebangsaan berarti sebuah proses penanaman ideologis yang menumbuhkan kesadaran bahwa bangsa Indonesia merupakan negara satu kesatuan yang meliputi politik, sosial-budaya dan ekonomi. Kesadaran ini harus selalu dipupuk baik melalui forum ilmiah maupun non ilmiah karena dengan cara ini kelak kesadaran diri ini dapat menimbulkan rasa memiliki dan cinta terhadap tanah air dan bangsa Indonesia.

Sementara dalam pandangan Azra, salah satu unsur ciri khas gerakan radikalisme agama adalah anti terhadap ideologi dasar negara dan empat pilar bangsa Indonesia ; Pancasila, Bhineka Tunggal Ika, Negara Kesatuan Repunlik Indonesia dan Undang Undang Dasar. Selain itu mereka juga menunjukkan sikap mudah mengkafirkan orang yang tidak sepaham dengan mereka meski seagama dan sikap intoleran terhadap penganut agama lain(Azra, 2018). Anti terhadap ideologi pancasila dan berupaya ingin menggantinya dengan ideologi lain adalah sebuah sikap makar yang harus terus dilawan. Sikap seperti ini bermula dari doktrin 'takfiri' yang menganggap bahwa Indonesia adalah negara kufur karena menganut sistem demokrasi yang bersumber dari negara yang mereka anggap kafir.

Radikalisme yang berupa sikap menolak keberadaan NKRI dan berupaya merongrong persatuan bangsa sangat membahayakan bagi keberlangsungan berbangsa dan bernegara. Akibat yang ditimbulkan bukan hanya kerusakan secara fisik melainkan juga menurunya trust kepada pemerintah. Dalam dasawarsa terakhir, isu atas penolakan ideologi dasar negara, Pancasila, muncul kembali di tengah masyarakat dan bahkan lebih kuat. Diantara mereka ada yang berani secara terbuka dan terang-terangan mengemukakan ketidak setujuan mereka terhadap Pancasila sebagai ideologi negara yang sudah dibangun oleh pendiri bangsa secara mufakat. Sebagian yang lain masih ber andai-andai ingin menempatkan kembali tujuh kata yang terdapat pada sila pertama yang dihapus sebagaimana yang tertulis dalam piagam Jakarta.

Selain dua kelompok diatas, juga ada sekelompok orang yang berpendapat bahwa syariat Islam wajib menjadi dasar negara dan menyatakan haram terhadap empat pilar bangsa Indonesia dan 
menganggap hal itu produk kafiryang harus dimusnahkan (Rohman, 2018). Sementara kelompok yang ingin mengganti ideologi pancasila ini sudah merangsek ke institusi pendidikan dengan siswa dan mahasiswa sebagai sasaranya. Kaitanya dengan hal ini, masjid Ulul Azmi melakukan satu upaya agar gerakan radikalisme agama dapat diantisipasi dengan baik. Salah satu bentuknya adalah dimasukkanya tema-tema tentang wawasan kebangsaan dan nasionalisme dalam kegiatan keagamaanya.

Menurut Afri, selaku pembina mahasiswa masjid, tema tentang kebangsaan dipilih untuk memperkuat nasionalisme dan paham kebangsaan kepada mahasiswa yang selama ini dijadikan alat oleh kelompok radikalisme untuk menggantinya dengan sistem baru yang bisa saja justru malah mengancam persatuan bangsa Indonesia. Wacana ideologi transnasional yang berupaya merubah sistem atau bentuk negara yang sudah mapan dan sering didengungkan oleh kelompok tertentu sangat beresiko jika diterima oleh kalangan mahasiswa pada khususnya. Pengakuan terhadap ideologi negara selain pancasila merupakan bagian upaya makaryang harus dilawan oleh segenap lapisan masyarakat. Dalam perjalanan sejarah, bangsa Indonesia sudah berkali-kali menghadapi 'gangguan' ideologi yang mencoba mengganti dasar negara dan selama ini bangsa ini mampu melewati rintangan tersebut. Meski begitu, segala upaya perlu terus dilaksanakan oleh semua pihak dan lapisan masyarakat guna mencegah merebaknya virus ideologi transnasional yang membahayakan intregitas bangsa.

Dalam konteks sejarah kemerdekaan bangsa Indonesia, nasionalisme yang berarti cinta tanah air pernah digaungkan oleh para 'ulama dalam melawan penjajah. Melalui jargon Hubbul Wathon Minal Iman (Cinta tanah air bagian dari Iman), para Ulama berhasil menggerakkan semangat masyarakat khususnya kalangan santri. Hal ini dilakukan semata-mata untuk merebut kembali kemerdekaan yang belum sempurna. Sehubungan dengan ini, peran kampus sangat strategis mengingat kampus sebagai institusi pendidikan tinggi yang didalamnya terdapat anak muda yang memiliki ghirah atau semangat ingin tahu yang menggebu dalam segala hal termasuk agama. Mereka mahasiswa yang juga dari berbagai latar belakang dan terkadang masih labil secara psikis membutuhkan pembimbing 
dalam memahami agama Islam. Disinilah letak peran masjid dalam membentuk karakter mahasiswa melalui kajian keagamaan dengan menanamkan nilai-nilai luhur pancasila serta memberi wawasan kebangsaan.

Dalam kajian rutin yang diadakan oleh pengurus masjid Ulul 'Azmi ini, selain mengkaji berbagai kitab kuning, tema kebangsaan merupakan tema yang dibahas dalam kajian rutin. Disamping itu, kajian kebangsaan juga diadakan dalam rangka Peringatan Hari Besar Nasional (PHBN) seperti memperingati hari kemerdekaan Indonesia. Pengurus masjid mengadakan kajian kebangsaan ini dengan tujuan memperkuat nasionalisme sebagaimana yang pernah diamanatkan oleh Presiden Republik Indonesia, Joko Widodo saat bertemu dengan para rektor pergiruan tinggi se-Indonesia di Bali. Dalam perpektif lain, pengakuan terhadap keberagaman, perbedaan dan kemajemukan budaya, ras, suku, etnis bahkan agama merupakan konsep multikulturalisme. Sebuah konsep yang memberikan pemahaman bahwa bangsa yang plural atau mejemuk adalah bangsa yang dipenuhi dengan budaya yang beragam (Malla, 2017).

\section{Perketat Izin Kegiatan}

Dalam menjalankan misinya, kelompok radikalisme tidak melakukanya secara individu tanpa komando, melainkan terorganisir dan terkontrol. Mereka tak segan-segan membuat kajian keagamaan di lingkungan kampus untuk menarik perhatian mahasiswa yang memiliki keinginan yang menggebu dalam beragama. Bentuk kajian yang dilakukan dengan cara melingkar yang terdiri dari kurang lebih 10 - 15 anak dan dilakukan secara intens didalam kampus bahkan ada yang menggunakan fasilitas masjid kampus. Kajian model seperti ini sering dijumpai dikampus manapun baik Perguruan

Tinggi Keagamaan maupun Perguruan Tinggi Umum (Perguruan Tinggi Negeri) non keagamaan.

Universitas Airlangga Surabaya merupakan salah satu kampus yang sering terlihat adanya kajian keagamaan dengan model diatas. Secara teknis, bentuk kajian ini tidak ada yang 'aneh' atau biasa-biasa saja dan merupakan sesuatu yang boleh dikatakan wajar. Namun, menjadi masalah jika dilihat dari segi materi kajian yang dijadikan 
bahan diskusi. Tema-tema yang dijadikan topik kajian seringkali mengarah pada sesuatu yang sensitif bagi kalangan umat Islam. Bahkan apabila topik tersebut salah dipahami bisa menimbulkan kegaduhan tersendiri. Kesalahpahaman tersebut timbul akibat kekeliruan dalam memahami materi yang disebabkan oleh penjelasan narasumber atau mentor yang tidak dijelaskan secara konperehensif. Hal inilah yang menjadi kekhawatiran pengurus masjid Ulul 'Azmi, sehingga ada sebuah kebijakan bahwa apabila ada kajian yang dilakukan secara berkelompok yang dilakukan oleh mahasiswa dari organisasi eksternal kampus, pengurus masjid berhak membubarkan kajian tersebut.

Menurut penuturan direktur kemahasiswaan, bapak Hadi, beberapa tahun yang lalu masjid Ulul Azmi memilki program Pembinaan Baca Al-Qur'an (PBA) yang bertujuan untuk mendalami materi keagamaan oleh mahasiswa Unair. Program ini diikuti oleh mahasiswa baru yang dibina oleh beberapa mentor agama. Namun dalam perkembanganya justru program PBA ini dijadikan lahan bagi kelompok-kelompok tertentu untuk menyemai ideologi mereka dikalangan mahasiswa. Melihat fenomena ini, kampus, melalui Direktur Kemahasiswaan dan dilaksanakan oleh pengurus masjid menghentikan program PBA ini dengan alasan tersebut. Kebijakan ini merupakan bagian dari upaya kampus melalui masjidnya menangkal faham-faham yang bertentangan dengan ideologi negara atau kelompok radikalisme agama.

Selain itu, pihak pengurus masjid melakukan screning secara ketat terhadap organisasi mahasiswa eksternal. Antisipasi yang dilakukan oleh pengurus masjid meliputi berbagai sisi, diantarnya, izin kegiatan, narasumber yang mengisi kajian, imam masjid dan edaran tulisan yang dibagikan setiap hari jum'at. Dalam struktur kepengurusan masjid Ulul 'Azmi, ada lima orang sebagai penanggungjawab kepengurusan masjid Ulul Azmi yang masingmasing memilki tupoksi yang berbeda-beda. Kelima orang tersebut disebut dengan istilah manager. Para manager ini diambil dari jajaran pejabat kampus, sedangkan kelima managertersebut adalah, manager dakwah, manager sarpras, manager keuangan, manager ritual dan PHBI serta manager sosial dan usaha. Sebagai bentuk keseriusan dalam mengelola kegiatan, para manager tersebut 
mendapat pengakuan legal-formal berupa Surat Keputusan Rektor. Hal ini bertujuan agar apapun bentuk kegiatan yang diadakan di masjid dapat dengan mudah dikontrol dan diawasi oleh jajaran rektorat.

Pelaksana kajian keagamaan yang melibatkan unsur mahasiswa yang telah ditunjuk oleh rektorat. Mereka diberi wadah dalam satu komunitas bernama MAJID (Mahasiswa Masjid) dan bertanggung jawab langsung kepada pengurus masjid (manager bidang dakwah) yang mendapatkan mandat langsung dari Rektor. MAJID ini semacam REMAS (Remaja Masjid) dalam struktur kepengurusan di masjid pada umumnya. Secara teknis, MAJID inilah yang bertugas menyusun dan memprogram jadwal kegiatan sekaligus mengondisikan mahasiswa dan jamaah untuk berpatisipasi dalam kegiatan masjid yang kemudian dibantu oleh pembina MAJID. Kegiatan yang telah disusun selanjutnya dikomunikasikan kepada pembina dan pengurus masjid sebagai bentuk kontrol terhadap materi tersebut. selain itu, koordinasi juga dilakukan untuk mengantisipasi organisasi kemahasiswaan baik internal maupun eksternal yang akan menggunakan fasilitas masjid.

Menurut Afri, selaku pembina MAJID, seringkali beberapa organisasi eksternal mahasiswa yang berafiliasi dengan kelompok tertentu meminta izin mengadakan kegiatan keagamaan di masjid Ulul Azmi. Mereka bukan hanya ingin mengadakan kegiatan keagamaan namun juga membagikan pamflet maupun artikel yang konten isinya mengandung muatan radikalisme agama. Menyikapi hal ini, pengurus masjid melakukan verifikasi terhadap organisasi tersebut dan apabila ditengarai ada yang berafiliasi dengan kelompok radikal-intoleran maka sebagai bentuk pencegahan, pembina dan jajaran manager masjid tidak akan memberikan izin terhadap adanya kegiatan yang diadakan oleh mereka, termasuk penyebaran selebaran tulisan atau pamflet juga diseleksi dengan ketat oleh pengelola masjid. Koordinasi semacam ini bertujuan untuk tidak memberikan ruang kepada kelompok-kelompok intoleran maupun radikal yang menginginkan masjid kampus sebagai sarana penyebaran paham radikalisme. 


\section{Kesimpulan}

Bahwa dalam upaya menangkal paham radikalisme dikalangan mahasiswa, masjid kampus memiliki peran yang sangat penting. Ada beberapa usaha yang dilakukan melalui kegiatan keagamaan yang rutin dilaksanakan baik yang sifatnya rutinitas maupun eventual, diantaranya: Pengurus masjid mendesain kajian keagamaanya dalam bentuk penguatan ideologi islam moderat dan wawasan kebangsaan. Mereka sadar bahwa ideologi dapat dihadapi dengan ideologi. Radikalisme yang memilki watak intoleran dan eksklusif haruslah diimbangi dengan sajian ideologi moderat dan toleran. Selain itu, kelompok radikalis agama menginginkan perubahan besar dan mendasar dalam bangsa Indonesia yang justru dengan perubahan itu dikhawatirkan muncul disintergrasi dan disorientasi bangsa. Mereka menginginkan adanya formalisasi syari'at Islam yang dianggapnya sebuah solusi yang ideal. Menyikapi hal ini, pengurus masjid Ulul 'Azmi membuat beberapa kajian yang membahas tentang penguatan wawasan kebangsaaan dan nasionalisme. Ada yang sifatnya eventual seperti perayaan kemerdekaan Indonesia maupun kajian rutin yang menyesuakan momentum.

Pengurus masjid selektif dalam memberikan izin kegiatan keagamaan di masjid Ulul 'Azmi. Izin diperketat dengan harapan agar fasilitas masjid kampus tidak disalahgunakan untuk halhal yang bertentangan dengan semangat menyebarkan Islam rabmatan lil alamin. Dalam struktur kepengurusan masjid, melibatkan pejabat kampus, dosen dan mahasiswa. Hal ini untuk mempermudah pengawasan terhadap kegiatan apapun yang menggunakan masjid kampus. Pengawasan dan memperketat izin ini berlaku bagi organisasi apapun terutama organisasi eksternal kampus. Selain perketat izin kegiatan, pengurus masjid juga sangat selektif terhadap propaganda yang dilakukan kelompok tertentu melalui penyebaran pamflet dilingkungan masjid Ulul 'Azmi Universitas Airlangga Surabaya. 


\section{Daftar Pustaka}

A.S. Hikam, M. (2016). Deradikalisasi: Peran Masyarakat Sipil Indonesia Membendung Radikalisme. jakarta: PT Kompas Media Nusantara.

Abdi, A. P. (2019). Setara Institute Sebut 10 Kampus Terpapar Paham Radikalisme. Tirto.Id.

Abdullah, M. (2011). Pluralisme Agama dan Kerukunan dalam Keagamaan. Jakarta: Buku Kompas.

Adityani Putri, A. (2018). Pengaruh Intensitas Mengikuti Pengajian Kitab Al-Hikam Terhadap Tingkat Optimisme Dalam Memaknai Hidup. Universitas Islam Negeri Walisongo.

Azra, A. (2018). Melindungi Kampus. Kompas, p. 1. Retrieved from https://www.pressreader.com/indonesia/kompas/20180614/ page/1

Depdikbud. (1995). Kamus Besar Bahasa Indonesia. Jakarta: Balai Pustaka.

Djunaidi, A., Irfan, L. A., \& Safitri, E. (2016). Kebangkitan masjid kampus di yogyakarta: eksklusif atau inklusif? Millah, XV(2).

Gumelar, A. (2018). Pemahaman wawasan kebangsaan.

Hadi, O. (n.d.). Nation and Character Building Melalui Pemahaman Wawasan Kebangsaan. Direktorat Politik, Komunikasi, Dan Informasi Bappenas.

Hidayatulloh, M. S. (2015). Deradikalisasi Agama Dalam Pendidikan (Studi Kasus Terhadap Mata kuliah PAI di Institut Teknologi Sepulub Nopember Surabaya).

Kurniawan, S. (2014). Masjid Dalam Lintasan Sejarah Umat Islam. Jurnal Khatulistiwa-Journal of Islamic Studies, 4(September), 169.

Laksana, A. B. (2017). Radikalisme, Awas Kampus, Masuk. Yayasan BP Basis.

Lestari, S. (2016). A. muda I. makin radikal? R. from B. website: https:// www. bbc. com/indonesia/berita_indonesia/2016/02/160218_ 
indonesia_radikalisme_anak_mudar. (2016). Anak-anak muda Indonesia makin radikal? Retrieved from BBC website: https:// www.bbc.com/indonesia/berita_indonesia/2016/02/160218_ indonesia_radikalisme_anak_muda

Mahfud, C., Prasetyawati, N., Wahyuddin, W., Agustin, D. S. Y., \& Sukmawati, H. (2018). Religious Radicalism, Global Terrorism and Islamic Challenges in Contemporary Indonesia. Jurnal Sosial Humaniora, 11(1), 8.

Malla, H. A. B. (2017). Pembelajaran Pendidikan Agama Islam Berbasis Multikultural Humanistik dalam Membentuk Budaya Toleransi Peserta Didik Di SMA Negeri Model Madani Palu, Sulawesi Tengah. Inferensi, 11(1), 163.

Miftahuddin. (n.d.). Islam Moderat Konteks Indonesia dalam Perspektif Historis.

Muhsin, I., \& Gufron, M. (2018). Geliat Puritanisme Islam di Indonesia: Menyibak Tabir di Balik Gerakan Majelis Tafsir Al-Qur' an ( MTA ) dalam Perspektif Sosiologis Pendahuluan dengan praktik keagamaan umat Islam yang menyatukan prinsip- Islam tradisional ini tergambarkan dengan baik. INFERENSI, Jurnal Penelitian Sosial Keagamaan, 12(1), 213238.

Muhsin, I., Rochmawati, N., \& Huda, M. C. (2019). Revolution of Islamic Proselytizing Organization: From Islamism to Moderate. QIJIS (Qudus International Journal of Islamic Studies), 7(1).

Nisa', K. (2016). Al-Ghazali : Ihya' Ulum al-Din dan Pembacanya. Ummul Qura, VII, No. 2, 1.

Nur Syam. (n.d.). Deradikalisasi Melalui Pendidikan Tinggi.

Rohman, F. (2018). Pendidikan Wawasan Kebangsaan Dengan Pendekatan Bayani Di Pondok Pesantren Darul Falah Bangsri Jepara. Edukasia : Jurnal Penelitian Pendidikan Islam, 13(1), 53-78.

S.K., W. (2017). Wawasan Kebangsaan Dalam Wadah Negara Kesatuan Republik Indonesia. Jurnal Ketahanan Nasional, Vol. 12, pp. 65-71. 
Saifuddin. (2017). Radikalisme Islam Di Kalangan Mahasiswa (Sebuah Metamorfosa Baru). Analisis : Jurnal Studi Keislaman, 11(1), 17-32. https://doi.org/10.42042/ANALISIS.V11I1.605

Saputra, F. (2015). Hubungan Harga Diri Perilaku Menyontek Pada Mahasiswa.

Syaodih Sukmadinata, N. (2009). Metode Penelitian Pendidikan. Bandung: PT Remaja Rosdakarya.

Tahir, Q., Cangar, H., Syam, B., Komunikasi, I., Hasanuddin, U., Komunikasi, B., ... Hasanuddin, U. (2014). Masjid Kampus Sebagai Media Komunikasi Mahasiswa Campus Mosque Roles As Da' wah Activists Communications Media In The Students ' Character. Jurnal Komunikasi KAREBA, 3(3).

Toto, S. (2017). Indonesianisasi Islam : Penguatan Islam Moderat Dalam Lembaga Pendidikan Islam. Al-Tahrir, 17, 164. 